\title{
Environmental Justice at School: Understanding Research, Policy, and Practice to Improve Our Children's Health
}

Natalie Sampson, MPH

\begin{abstract}
BACKGROUND: No overarching federal agencies or policies are responsible for ensuring environmental health at schools in the United States, potentially allowing many inequities for low-income and minority communities to persist. This article examines emergent research, policy, and practice-based efforts that may be used to identify and address environmental justice at school.
\end{abstract}

METHODS: A brief literature review was conducted to understand (1) major mental, behavioral, and physical outcomes associated with environmental risk for school-aged children and (2) current research methods for assessing these relationships. Documents prepared by government agencies, school districts, and advocacy groups were also collected and synthesized to improve understanding of the state of planning and policies for maintaining or improving school environments.

RESULTS: Environmental risk can manifest in diverse ways such as mold, poor air quality, poor community design, or contaminated playgrounds. Deeply rooted in national and state structures of school funding and planning, such risks can lead to outcomes including respiratory illness, poor performance in school, and reduced levels of physical activity. With growing attention to these concerns, methods for measuring environmental risks and underlying disparities have advanced tremendously in the last few decades, yet development of innovative research approaches may be necessary to further advance and evaluate appropriate interventions.

CONCLUSIONS: Environmental injustice is generally unacknowledged during decision-making in US school districts. Continued dialogue reflective of translatable science is necessary to support school districts with limited funding in ensuring safe, healthy environments for learning.

Keywords: child and adolescent health; environmental health; policy.

Citation: Sampson N. Environmental justice at school: understanding research, policy, and practice to improve our children's health. J Sch Health. 2012; 82: 246-252.

Received on April 29, 2011

Accepted on November 24, 2011

\begin{abstract}
Tnsufficient consideration is given to potential schoolLased environmental health threats incurred by the nearly 63 million $^{1}$ youth enrolled in elementary and secondary schools in the United States. From building materials to heating and cooling systems, from surrounding air and noise quality to the adjacent neighborhood's land use, the environment of a school can create many opportunities for health or illness within children's vulnerable, developing bodies. Planners, environmental scientists, educators, and public health scholars attempt to link environmental health outcomes to school settings, including respiratory illness, ${ }^{2-4}$ mental health, ${ }^{5}$ crime or behavioral disorders, ${ }^{6,7}$ attendance, ${ }^{8}$ and academic performance. $^{9-11}$ The disproportionate distribution of
\end{abstract}

these risks and associated outcomes generally indicate inequitable conditions for already marginalized, low-income communities. ${ }^{12,13}$

Many argue that environmental health and safety inherently falls under the mission of the US education system to assure quality education and protect children, ${ }^{14}$ yet lack of local or federal policies on school siting, building, and maintenance do not reflect this charge. Education is not a fundamental right of the US Constitution, taking different forms at the state level. ${ }^{15}$ For instance, 43 states do not have a law to prevent communities from building schools on or near toxic waste, only 6 states have policies indicating if or how close a school can be built to a major source of air pollution, and only 6 states legally require environmental

Doctoral Candidate, (nsampson@umich.edu), Department of Health Behavior and Health Education, University of Michigan, School of Public Health, 1415 Washington Heights, Ann Arbor, Ml, 48109.

Address correspondence to: Natalie Sampson, Doctoral Candidate, (nsampson@umich.edu), Department of Health Behavior and Health Education, University of Michigan, School of Public Health, 1415 Washington Heights, Ann Arbor, MI, 48109. 
assessments in school siting processes. ${ }^{16}$ No federal agencies are responsible for school environmental health. This lack of policy may contribute to inequities when poorer school districts cannot afford the same environmental health amenities as nearby wealthier districts.

This article (1) broadly identifies and evaluates current literature on environmental health risks and outcomes for US elementary and secondary students in the context of environmental justice, or EJ, (2) summarizes and interrogates related research, policies, and practices to address EJ at school, and (3) offers next steps for decision-makers and scholars to minimize inequities.

\section{WHY INVESTIGATE SCHOOLS AS AN EJ ISSUE?}

According to the U.S. Environmental Protection Agency (EPA), EJ is:

...the fair treatment and meaningful involvement of all people regardless of race, color, national origin, or income with respect to the development, implementation, and enforcement of environmental laws, regulations, and policies. EPA has this goal for all communities and persons across this Nation. It will be achieved when everyone enjoys the same degree of protection from environmental health hazards and equal access to the decision-making process to have a healthy environment in which to live, learn, and work. ${ }^{17}$

The EJ movement's birth is often associated with the publication of a seminal report by the United Church of Christ in 1987, which was among the first to highlight the correlation between hazardous waste facility siting and race in the United States. ${ }^{18}$ Researchers such as Asch and Seneca noted similar relationships earlier in the late 1970s, reporting the unequal distribution of air pollution based on social and economic factors and corroborating emergent research of their contemporaries. ${ }^{19}$ In the last few decades, the EJ movement has extended to include green jobs, transportation, access to green space, and other dimensions of sustainability. In a timely manner, schools have entered the discussion.

School environmental injustice can occur in 2 instances: (1) when a school is sited on or near a hazardous location (eg, Brownfield sites, freight gateways) or (2) in how society implements or funds strategies to mitigate or maintain a healthy environment for children at an existing school. Little systematic evidence summarizes distribution of funding for existing schools through an EJ lens, although economic disparity between schools is well documented..$^{20}$ Regarding school siting, there is much disagreement if environmental injustice results from institutional discrimination in planning, economies of agglomeration (ie, clustering of related industries), or a historical combination of these forces. Studies have slowly materialized to understand these temporal relationships. ${ }^{21}$

\section{LITERATURE REVIEW}

\section{Environmental Exposures at School}

Whereas educators strive to ensure safe environments for their students, many imperceptible environmental risks may remain in the transfer to and from school, in the classroom, and on the playground where, in combination, children spend significant portions of their day. Potential exposures in school include psychological stressors, mold, volatile organic compounds, noise, particulate matter, airborne metals, lighting, radon, asbestos, and polyvinyl chloride. Per unit of body weight, children consume more water, food, and air than adult counterparts, and risk exposure is highest for young children due to characteristic hand-to-mouth and playtime behaviors (eg, playing closer to contaminated soil). Children have less metabolic tissue, detoxifying and excreting toxins at a slower rate than adults. Perhaps, the most frequently referenced exposure in school and environmental health literature is air quality as risk factor for respiratory illness. ${ }^{2-4}$ This emphasis is likely partially due to public health's interest in addressing asthma's high prevalence and related disparities, as approximately 7 million children in the United States have asthma. ${ }^{22}$

Many recent studies characterize potential threats to air quality at schools, some with attention to inequities. Assessing land use, some researchers have shown a blatant correlation between school racial/ethnic and income composition and government identified hazardous sites (eg, Toxic Release Inventory, Superfund) that may contribute to poorer air quality. ${ }^{23-25}$ Internationally, several studies generally conclude that outdoor air quality, and thus nearby land use, greatly affects indoor exposures, where concentration of pollutant particles is inversely related to indoor/outdoor air exchange rates. ${ }^{26,27}$ More specifically, studies have found concerning correlations between outdoor and indoor air quality in recreational areas, such as gyms, where children's respiration, and consequently intake of pollutants, is increased. ${ }^{28,29}$ Additional studies highlight how effective ventilation can reduce gaseous and particle pollution in schools, motivating conversation on the critical role of fans, windows, and heating, ventilation and air conditioning (HVAC) systems as interventions for children's health. ${ }^{30,31}$

\section{Environmental Health Outcomes at School}

A wide range of outcomes may materialize in the context of one's school environment: respiratory illness, behavioral outcomes, mental health, physical activity, and academic performance. These outcomes 
may be triggered by school- or home-based risks, or combination of difficult to differentiate exposure sources. For example, a child with asthma exacerbated by pollution from truck traffic driving past their school's playground may experience sleep deprivation from asthma symptoms, and this may lead to low academic performance. ${ }^{10}$ These outcomes may also reflect complicated gene-environment interactions, as is noted with asthma. ${ }^{2}$ Here, these outcomes are briefly described independently with intent of introduction.

Asthma is the most prevalent chronic illness among children in the United States with apparent disparities, $^{32}$ and healthy school environments may be able to prevent or mitigate its symptoms. Whereas the etiology of asthma is complex, entailing genetic, physiological, and multiple environmental predictors, effective management is possible for many. Schools can be the source of mold, vermin, dust, chemicals from cleaning supplies, poor air quality, or other such hazards that trigger asthma symptoms. By identifying schools with high student asthma prevalence and improving understanding of school construction and maintenance, districts can take measures to prevent asthma disparities. To this end, many observational studies have looked at school-based cohorts to understand asthma, ${ }^{3}$ and many interventional studies have used school-based settings to implement programs for effective asthma management. ${ }^{33}$

In recent decades, environmental epidemiologists have also discussed the relationship between neurotoxins (ie, toxins that affect nerve cells), such as lead, mercury, and carbon monoxide, and behavioral outcomes with some potentially controversial but relevant findings for schools to consider. Using longitudinal data, Nevin found that murder rates across the United States were highly correlated with preschool blood lead levels. ${ }^{6}$ Stretsky and Lynch associated industrial lead exposure during childhood with murder rates. ${ }^{34}$ More recently, researchers have uncovered spatial relationships between air pollution and common neurological disorders such as autism. ${ }^{35}$ Research implies that chronic exposure to neurotoxins at school or when school-aged could have effects over the course of one's lifetime. More longitudinal work is needed to understand potential confounders, however, such as poverty and childhood housing that may place children at risk. With thousands of understudied neurotoxins emitted each day in the United States, research of chronic exposure and intervention lags.

Academic performance, intelligence, reading comprehension, and other such variables are of utmost importance to educators, especially when funding to do their work may rely on these measures. Clark et al measured noise exposure in the school environment finding cumulative effects on reading comprehension for students attending schools near major European airports. ${ }^{9}$ Complementing their extensive, related work in Southern California, Pastor et al found that air toxic hot spots were predictive of lower academic test scores, even when key demographic variables were controlled. ${ }^{4}$ In Korea, Kim et al uniquely assessed the interactive effects of manganese and lead exposure of school-aged children which negatively affected intelligence. ${ }^{36}$ Although it is sometimes unclear where these exposures occur, schools may benefit from increased awareness of dangerous, potentially interactive combinations of noise, metal, or gaseous pollutants. This awareness could enable them to prevent classroom exposures in a precautionary manner or allow public health practitioners to conduct schoolbased screenings or interventions to reach families.

The built environment can directly and indirectly influence one's psychological well-being, ${ }^{5}$ and whereas this relationship is not extensively studied in the context of schools, it is another germane health outcome when striving for EJ at school. Evidence has repeatedly shown that people of lower socioeconomic status tend to live in subpar environmental conditions, leading to psychological distress and social isolation. ${ }^{5}$ Researchers have associated neighborhood crime and disorder with negative physical, mental, and emotional conditions. ${ }^{37}$ Conversely, there is a burgeoning understanding of the restorative powers of natural, clean outdoor environments. ${ }^{38}$ The schoolyard scene and school building conditions may have unknown effects on children's well-being, which currently remain poorly understood.

The built environment may also inhibit or facilitate physical activity at schools, a behavior associated with a host of chronic illnesses including obesity and cardiovascular disease. Schools present opportunities for physical activity by encouraging utilitarian commute behaviors, such as walking and biking to school or scheduled play during recess or sports. These opportunities emerge through community design and various programs such as Safe Routes to Schools with its walking school buses. Childhood overweight has been associated with neighborhood physical disorder, neighborhoods built after 1969, and higher convenience store density. ${ }^{39}$ There are a vast number of community design variables explored by Smart Growth, New Urbanism, and other planning frameworks that may dramatically influence a child's level of activity between school and home: percentage of trees, land use, connectivity, disorder, acreage of parks, and number and types of food stores. Environmental justice also entails understanding these community design features near schools.

\section{DISCUSSION}

\section{Considerations for Research}

There is a host of methodological challenges when determining the existence and degree of 
environmental injustice at schools. ${ }^{26}$ These include, but are not limited to, selecting appropriate spatial units of analysis, accurately locating and attributing sources of exposure or outcomes, and distinguishing main and interactive effects for multiple, compounding exposures. The consequences of choosing between census tracts, zip codes, block groups, or other spatial dimensions as study units are not always acknowledged. Many studies use unit-hazard coincidence methods to measure exposure. ${ }^{40}$ This means, for instance, that a researcher may indicate that 2 people in the same census tract are categorically exposed to a pollutant; however, l person may live next to the emitting source, while the other person may live several miles away. In response, Mohai and Saha closely investigated multiple approaches to spatial analysis, testing various distance-based methods to improve upon limitations in unit-hazard models. ${ }^{40}$ Depending on many factors, an "unsafe" distance from an environmental hazard to live, work, or play within may vary based on wind patterns, types of air mass, temperature, type of pollutant, and the source of the pollutant, as estimates from intricate atmospheric dispersion models suggest. Within these spatial units, it is often difficult to distinguish and assess cumulative, interactive environmental health exposures as was done by Kim et al. ${ }^{36}$ For instance, when assessing students' exposure to poor air quality, does a study account for each participating school's major mobile and nonmobile sources of pollution?

Also, many studies assessing EJ at schools are shaped by available data and their units of analysis, rather than research questions. For instance, census data, which are often used to report socioeconomic position at individual or school levels, are often inaccurate representations. Health data are often not available at the appropriate geographic levels and may not include longitudinal information. To understand the temporal role of economies of agglomeration and compounding hazards, measures of land use near schools may also be helpful, although this may be a difficult endeavor, likely requiring collection of diverse data sets from regional planning organizations.

\section{Implications for Research}

More translational research and evaluation may be necessary to direct future policy and practice. First, researchers must continue to conduct exposure studies to identify potential causal main and interaction effects of environmental risks at schools, advancing underlying methods and data tracking. Also, while rarely discussed in the context of schools, there appears to be opportunity for community-driven approaches to risk identification through Health Impact Assessments (HIAs) ${ }^{41}$ and participatory research ${ }^{42}$ which may help researchers to identify compounding sources of environmental injustice in a community that may not be their own. Health Impact Assessments are voluntary tools to assess health indicators usually identified by public participants. In relation to air quality, dispersion models are needed to assist policymakers in setting minimum distance thresholds between schools and pollutants, where the precautionary principle is sometimes overridden by political constraints. ${ }^{13}$ Also concerning air quality, natural experiments may identify HVAC design, materials, and energy use that are both financially feasible and environmentally sound. Finally, intervention evaluation must continue in order to disseminate facilitators and barriers of local efforts for school districts to learn from nationally.

\section{Considerations for Policy and Practice}

Conflict occurs when communities must make decisions on transportation, school siting, building materials, and classroom supplies with limited budgets, leaving stakeholders innately at fiscal odds. School funding is different state-by-state, but most public schools rely on a combination of (1) federal funds (about 10\%), mostly from individual and corporate income taxes, (2) state funds (about 40\%-70\%) from various state taxes or programs (eg, lotteries), and (3) local funds (about 20\%-50\%) from bonds, mileages, and property taxes. ${ }^{43}$ For many states, this funding is severely differential between districts, which is where many decisions are made, perpetuating severe inequities in quality and quantity of education. ${ }^{16}$ In several states, schools receive per pupil monetary allotments leading them to market their schools to attract families. Some argue this may shift limited dollars from teachers and curriculum to the construction of ostentatious, new, and sometimes, unnecessary buildings. ${ }^{44}$ Meanwhile, the recent US economic decline and draining of 2009 American Recovery and Reinvestment education funds have led to drastic budget cuts and political response from teachers' unions across the country. In the United States, budgets for all school construction, both new buildings and modifications to existing buildings, have decreased from approximately $\$ 23$ billion in 2005 to $\$ 13$ billion in $2011 .{ }^{45}$ Even with fewer funds, not all environmental health reforms are irrelevant, farfetched, and cost-prohibitive options to disregard in this economic climate; green cleaning supplies, integrated pest management, and energy efficient HVAC systems or building decisions may have noteworthy long-term cost savings. ${ }^{14}$

In addition, regional planning must be considered in the discussion of EJ and schools. Planning dramatically influences school siting decisions, and thus students' potential exposure to traffic, sidewalks, hazardous facilities, psychological stressors, or other features of the built environment. In many states, schools have minimum acreage requirements for siting, which can greatly limit district options. Appatova et al reported 
that over $30 \%$ of US public schools are within 400 $\mathrm{m}$ of a major highway and $10 \%$ are within $100 \mathrm{~m} .{ }^{46}$ Yet, it is not as simple as moving schools away from truck traffic characteristic of urban settings. America's sprawling landscape of "leapfrog" suburbs can be unhealthy too, where biking and walking to school is unsafe or not feasible over long distances without sidewalks, and caregivers and buses must consume excessive amounts of gas to get children to class. The planner's trade-offs have vast environmental, cultural, economic, and health implications, and all must be considered when boards are deciding whether to close or open a school or whether to build a new building or mend an existing one.

\section{Implications for Policy and Practice}

The potential response to environmental injustice in schools is as complex as the problems themselves. An optimistic recommendation would be major restructuring of education funding to redistribute dollars more equally among all schools, benefiting a host of inequities beyond environmental health. ${ }^{15}$ Local districts should fund and support new Leadership in Energy and Environmental Design-certified school buildings in a walkable, natural setting if their community enables them. However, it remains a national civil rights issue if the adjacent school or district is dealing with mold and vermin in their dilapidated facility with poor ventilation next to a highway entrance ramp. As we are unlikely to see a drastic reinvention of the US education system, there are key, practical suggestions where progress can and, in some cases, is being made at federal, state, and local levels.

State or federal guidelines may address the limitations of pluralistic local policies, and 3 types could be immediately helpful: school siting policies, recommended guidelines for EJ at schools, and continued improvement of vehicle emission standards. Federal or state school siting policies may be an option, such as those seen in California which mandate "no (new school) site within $500 \mathrm{ft}$ of the edge of the closest traffic lane of a freeway or busy traffic corridor" ${ }^{\prime 4}$ and "no school construction on any hazardous substance release site listed by state." 48 However, many of these laws do not require a complementary provision that prevents new major highways or industrial sites from being built near existing schools. Second, as required by the 2007 Energy Independence $\delta$ Security Act, the EPA's community guidelines for siting schools highlight voluntary strategies for public involvement, setting local siting criteria, conducting environmental reviews, drafting state or tribal policies, and identifying environmental issues at schools and potential remediation. ${ }^{49}$ Recently approved, these guidelines and resources may assist already overburdened districts, as would ongoing trainings and evaluation to share lessons learned. Finally, efforts by the EPA to continue reduction of emissions of heavy-duty engines are needed to improve air quality by schools that are at risk and unlikely to relocate in the near future. In 2010 and 2011, we saw the phase-in of several new standards for trucks and other freight vessels whose gaseous and particle emissions contribute to cardiovascular and respiratory illnesses. ${ }^{50}$ Whereas continued research is needed, existing findings sufficiently justify these steps.

Locally, there is much opportunity for increased fairness in school siting processes, as districts can often understand local context more accurately than state or federal governments. Strategies to address procedural justice in siting may include multisectoral planning teams, involvement of public health experts, siting advisory boards, or coalitions. ${ }^{44,45}$ Although school boards and administrators ultimately decide major building sites and design, teachers, parents, and students often enhance risk and solution identification. ${ }^{14}$ In many districts, these stakeholders successfully advocate for instrumental grants, engage students in applied environmental education, or execute green school programming. Their role cannot be underestimated in scoping, siting, environmental assessment, and longterm maintenance of school sites.

Guidance already exists for local programming to enable environmental health and justice at schools. Tools such as the EPA's Not in My Schoolyard, the National Research Council's Review and Assessment of the Health and Productivity Benefits of Green Schools: An Interim Report, and the Child Proofing Our Communities Campaign's report, Creating Safe Learning Zones: The $A B C$ 's of Healthy Schools are starting points. When considering building materials and energy efficiency, these publications share case studies, offering accessible models of cost-effective, environmentally healthy building design for facility managers and school boards to model. Foremost, justified by these resources and research on air quality at schools, thoughtful reflection of current HVAC is vital-where is the intake, where is the outtake, and are gyms, where student respiration increases, well designed? Everett-Jones et al, in a survey of more than 1000 schools, found that those with indoor air quality programs were more likely to have environmentally sound purchasing policies, conduct HVAC inspections, have smoke-free school policies, and have plans to address mold..$^{51}$ Guided by such examples, all districts can integrate environmental health into planning even within minimal means.

\section{CONCLUSION}

A review of literature notably indicates the chronic, compounding nature of environmental exposures that can affect the health of vulnerable, school-aged children. This ongoing exposure likely builds on a host 
of chronic stressors and discrimination most often already felt by those attending schools in low-income communities. ${ }^{52}$ Such health disadvantages could partially be addressed at school, early in children's lives, through collaborative efforts of policymakers, school boards, educators, planners, public health professionals, and communities. By continued translation of research that identifies disproportionate environmental burdens at schools, corrective interventions could effectively direct resources and support districts that need it most. Recent progress in multidisciplinary dissemination of related studies, development of programs and resources, and passage of relevant policies confirms that EJ at school requires national attention.

\section{REFERENCES}

1. National Center for Health Statistics. Digest of Education Statistics: 2010.Atlanta, GA: Centers for Disease Control and Prevention; 2010.

2. Eggleston P. The environment and asthma in US inner cities. Chest. 2007;132(S5):782S-788S.

3. McConnell R, Islam T, Shankardass K, et al. Childhood incident asthma and traffic-related air pollution at home and school. Environ Health Perspect. 2010;1 18(7):1021-1026.

4. Pastor M, Morello-Frosch R, Sadd JL. Breathless: schools, air toxics, and environmental justice in California. Pol Stud. 2006;34(3):337-362.

5. Evans GW. The built environment and mental health. $J$ Urban Health. 2003;80(4):536-555.

6. Nevin R. Understanding international crime trends: the legacy of preschool lead exposure. Environ Res. 2007;104(3):31-36.

7. Preston BL, Warren RC, Wooten SM, et al. Environmental health and antisocial behavior: implications for public policy. J Environ Health. 2001;63(9):9-19.

8. Shendell DG, Prill R, Fisk WJ, Apte MG, Blake D, Faulkner D. Associations between classroom $\mathrm{CO} 2$ concentrations and student attendance in Washington and Idaho. Indoor Air. 2004; 14(5):333-341.

9. Clark C, Martin R, van Kempen E, et al. Exposure-effect relations between aircraft and road traffic noise exposure at school and reading comprehension: the RANCH project. Am J Epidemiol. 2006;163(1):27-37.

10. Liberty KA, Pattemore P, Reid J, Tarren-Sweeney M. Beginning school with asthma independently predicts low achievement in a prospective cohort of children. Chest. 2010;138(6):1349-1355.

11. Zahran S, Mielke HW, Weiler S, Berry KJ, Gonzales C. Children's blood lead and standardized test performance response as indicators of neurotoxicity in metropolitan New Orleans elementary schools. Neurotoxicology. 2009;30(6):888-897.

12. Landrigan PJ, Rauh VA, Galvez MP. Environmental justice and the health of children. Mt Sinai J Med. 2010;77(2):178-187.

13. Morello-Frosch R, Pastor M Jr., Sadd J. Integrating environmental justice and the precautionary principle in research and policy making: the case of ambient air toxics exposures and health risks among schoolchildren in Los Angeles. Ann Amer Acad Polit Soc Sci. 2002;584:47-68.

14. Healthy Schools Network. Sick schools 2009; 2009. Available at: http://www.healthyschools.org/SICK_SCHOOLS_2009.pdf. Accessed November 8, 2011.

15. Neal D. Healthy schools: a major front in the fight for environmental justice. Lewis $\theta$ Clark L R.2008;38(2):473-493.
16. Rhode Island Legal Services. Not in my schoolyard: avoiding environmental hazards at school through improved school site selection policies; 2006. Available at: http://stage.nylpi.org/pub/ School_Siting_Final.pdf. Accessed November 8, 2011.

17. National Environmental Policy Act (NEPA). Exec. Order No. 12898, 42 U.S.C. $§ 4321$ (1994).

18. Bullard R, Mohai P, Saha R, Wright B. Toxic Wastes and Race at Twenty 1987-2007: Grassroots Struggles to Dismantle Environmental Racism in the United States. Cleveland, OH: United Church of Christ Justice and Witness Ministry; 2007.

19. Asch P, Seneca JJ. Some evidence on the distribution of air quality. Land Econ. 1978;54(3):278-279.

20. Fischel W. Making the Grade: The Economic Evolution of American School Districts. Chicago, IL: University of Chicago Press; 2009.

21. Norton R. Planning for school facilities: school board decisionmaking and local coordination in Michigan. J Plan Ed Res. 2007;26(4):478-496.

22. National Center for Health Statistics. National Health Interview Survey: 2008. Atlanta, GA: Centers for Disease Control and Prevention; 2009.

23. Gibbs C, Melvin JL. Structural disadvantage and the concentration of environmental hazards in school areas: a research note. Crime Law Soc Change. 2008;49(4):315-328.

24. Stretesky PB, Lynch MJ. Environmental hazards and school segregation in Hillsborough County, Florida, 1987-1999. Sociol Quart. 2002;43(4):553-573.

25. Pastor M, Sadd J, Morello-Frosch R. Who's minding the kids? Pollution, public schools and environmental justice in Los Angeles. Soc Sci Quart. 2002;83(1):263-280.

26. Mejia JF, Choy SL, Mengersen K, Morawska L. Methodology for assessing exposure and impacts of air pollutants in schools: data collection, analysis and health effects-a literature review. Atmos Environ. 2011;45(4):813-823.

27. Mullen NA, Bhangar S, Hering SV, Kreisberg NM, Nazaroff WW. Ultrafine particle concentrations and exposures in six elementary school classrooms in northern California. Indoor Air. 2011;21(1):77-87.

28. Branis M, Safranek J, Hytychova A. Exposure of children to airborne particulate matter of different size fractions during indoor physical education at school. Build Environ. 2009;44(6):1246-1252.

29. Suqanwaiphatthana W, Ruangdej K, Turner-Henson A. Outdoor air pollution and children's health. Pediatr Nurs. 2010;36(1):25-32.

30. Guo H, Morawska L, He C, Gilbert D. Impact of ventilation scenario on air exchange rates and on indoor particle number concentrations in an air-conditioned classroom. Atmos Environ. 2008;42(4):757-768.

31. Parker JL, Larson RR, Eskelson E, Wood EM, Veranth JM. Particle size distribution and composition in a mechanically ventilated school building during air pollution episodes. Indoor Air. 2008;18(5):386-393.

32. Akinbami L, Liu X, Moorman J. Asthma Prevalence, Health Care Use, and Mortality: United States, 2005-2009. (DHHS Publication No. (PHS) 2011-1250.) Hyattsville, MD: National Center for Health Statistics; 2011.

33. Coffman J, Cabana M, Yelin E. Do school-based asthma education programs improve self-management and health outcomes? Pediatrics. 2009;124(2):729-742.

34. Stretesky P, Lynch M. The relationship between lead exposure and homicide. Arch Pediatr Adolesc Med. 2001;155(5):579-582.

35. Volk HE, Hertz-Picciotto I, Delwiche L, Lurmann F, McConnell R. Residential proximity to freeways and autism in the CHARGE study. Environ Health Perspect. 2011;119(6):873-877.

36. Kim Y, Kim BN, Hong YC, et al. Co-exposure to environmental lead and manganese affects the intelligence of school-aged children. Neurotoxicology. 2009;30(4):564-571. 
37. Farquhar SA, Parker E, Schulz A, Israel B. In their words: how Detroit residents perceive the effects of their physical environment. Loc Environ. 2005; 10(3):259-274.

38. Faber Taylor A, Kuo FE, Sullivan WC. Views of nature and selfdiscipline: evidence from inner city children. J Environ Psych. 2002;22(1-2):49-63.

39. Grafova I. Overweight children: assessing the contribution of the built environment. Prev Med. 2008;47(3):304-308.

40. Mohai P, Saha R. Reassessing racial and socioeconomic disparities in environmental justice research. Demography. 2006;43(2):383-399.

41. Forsyth A, Slotterback CS, Krizek KJ. Health impact assessment in planning: development of the design for health HIA tools. Environ Impact Asses Rev. 2010;30(1);42-51.

42. Corburn J. Street Science: Community Knowledge and Environmental Health Justice. Cambridge, MA: MIT Press; 2005.

43. Carey K, Roza M. School funding's tragic flaw. Center for Reinventing Education; 2008. Available at: http://www.crpe.org/cs/ crpe/view/csr_pubs/227. Accessed November 8, 2011.

44. McClelland M, Schneider K. Hard lessons: causes and consequences of Michigan's school construction boom. Michigan Land Institute; 2004. Available at: http://www.mlui.org/growth management/fullarticle.asp?fileid $=16633$. Accessed November 8, 2011 .
45. Abramsom P. The 2011 school construction report. School Plann Man. 2011; 16: CR2-CR16.

46. Appatova A, Ryan P, LeMasters G, Grinshpun S. Proximal exposure of public schools and students to major roadways: a nationwide U.S. survey. J Environ Plann Man. 2008;51(5):631646.

47. California Code of Regulations. California Public Resources Code, Title XIV, §21151.8(a)(2)(2004).

48. California Code of Regulations. California Education Code, Title V, §17213(a)(2) (2001).

49. United State Environmental Protection Agency. School siting guidelines. Available at: http://www.epa.gov/schools/siting/ index.html. Accessed November 8, 2011.

50. United State Environmental Protection Agency. Transportation and climate. Available at: http://www.epa.gov/otaq/climate/ regulations.htm\#1-2. Accessed November 8, 2011.

51. Everett-Jones S, Smith AM, Wheeler LS, McManus T. School policies and practices that improve indoor air quality. J School Health. 2010;80(6):280-286.

52. Lantz P, House J, Mero R, Williams DR. Stress, life events, and socioeconomic disparities in health: results from the Americans' Changing Lives Study. J Health Soc Behav. 2005;46:274-288.

\section{$\begin{array}{llllllllll}\text { A S H A } & \text { P A R T N E R S }\end{array}$}

Platinum Endowment Partners

- Asthma Ready ${ }^{\circledR}$ Communities, University of Missouri Health Care, N601 Health Sciences Center, DC058.00, Columbia, Missouri 65211; www.asthmaready.org

- National Library of Medicine Grantee - University of Missouri, Sinclair School of Nursing, 324a School of Nursing Building, Columbia, Missouri 65211; www.missouri.edu

Gold Endowment Partners

- ArtsTech, A Center for Youth Enterprise, 1522 Holmes Street, Kansas City, Missouri; http://www.artstech-kc.org/

- Cerner Corportation, 2800 Rockcreek Parkway, Kansas City, Missouri 64117; www.cerner.com; www.firsthandfoundation.org

- Kansas Association of Health, Physical Education, Recreation and Dance, PO Box 11, Holcomb, Kansas 67851; http://www.kahperd.org/

- Kansas State Dept. of Education, Safe and Drug Free Schools, 120 SE 10th Avenue, Topeka, Kansas 66612; www.ksde.org

- MarshMedia, 8025 Ward Parkway Plaza, Kansas City, Missouri 64114; www.marshmedia.com

- Missouri Coordinated School Health Coalition, PO Box 309, Columbia, Missouri 65205 http://www.healthykidsmo.org/

- Missouri Dept. of Elementary and Secondary Education, PO Box 408, Jefferson City, Missouri 65102; www.dese.mo.gov

- The SPARK Programs, 438 Camino Del Rio South, San Diego, CA 92108; http://www.sparkpe.org/

- Wiley-Blackwell, 350 Main Street, Malden, MA 02148; http://www.wiley.com/WileyCDA/

Silver Endowment Partners

- Department of Applied Health Science, Indiana University, 1025 E. 7th Street, HPER 116, Bloomington, Indiana 47405;

http://www.indiana.edu/ aphealth/

- Kansas Coordinated School Health, 120 SE 10th Avenue, Topeka, Kansas 66612; www.kshealthykids.org/KCSH_Menus/KCSH_Home.htm

- Kansas State Dept. of Education, Special Education Services, 120 SE 10th Avenue, Topeka, Kansas 66612; www.ksde.org

Sustaining Partners

- American Cancer Society, School Health Project National Home Office, 143 Elizabeth Street, Saugatuck, Michigan 49453; www.cancer.org

- Center for American Indian Community Health, University of Kansas Medical Center, Office of Preventive Medicine, Kansas City, Kansas 66160; ww2.kumc.edu/hr/diversity/diversity.html

- University of Florida, Department Health Education \& Behavior, Gainesville, Florida 32611 http://www.hhp.ufl.edu/heb.php/

- Missouri Association of School Nurses, 2308 Ridgemont, Columbia, Missouri 65203-1542; http://www.missourischoolnurses.org/home/homepage.htm

Century Partners

- ASCD, 1703 N. Beauregard St, Alexandria Virginia 22311; www.ascd.org/

- Center for Health and Learning, 28 Vernon Street, Ste. 319, Brattleboro, Vermont 05301; www.healthandlearning.org

- GOJO Industries, P.O. Box 991, Akron, Ohio 44309; www.gojo.com/united-states/

- HealthTeacher, 5200 Maryland Way, Ste. 200, Brentwood, Tennessee 37027 www.healthteacher.com

- Kansas School Nurse Organization, 13174 X Road, Meriden, Kansas 66512; www.ksno.org

- Missouri Association for Health, Physical Education, Recreation, and Dance, 1220 W. Crestview Drive, Marysville, Missouri 64468; http://www.moahperd.org/

- National Association of State School Nurse Consultants, 4705 Circle Drive, Columbia, South Carolina 29206; www.nassnc.org

AMERICAN SCHOOL HEALTHASSOCIATION

4340 East West Highway - Suite 403 - Bethesda, MD 20814 - 301/652-8072 - www.ashaweb.org 